\title{
The Influence of Channel Environment on Use of Power
}

\author{
Guanglu Cao ${ }^{1}$ \\ ${ }^{1}$ Department of Marketing, School of Economics and Management, Tsinghua University, Beijing, China \\ Correspondence: Guanglu Cao, Department of Marketing, School of Economics and Management, Tsinghua \\ University, Beijing, China
}

Received: March 10, 2017

Accepted: April 2, 2017

Online Published: April 11, 2017

doi:10.5430/jbar.v6n1p39

URL: https://doi.org/10.5430/jbar.v6n1p39

\begin{abstract}
External environment has a vital impact on channel operation, but it remains unclear how task and institutional environment influence channel members' use of power. With data collected from distributors of a large-scale petrochemical enterprise, this study builds a structural equation model to analyze the impact of environment on channel members' behavior and relationship. The empirical results suggest that, both task and institutional environments are influential to channel behavior. In a dynamic environment, suppliers tend to use coercive power; and in a munificent environment, suppliers tend to use non-coercive strategy. When the regulatory environment is influential, suppliers tend to use coercive power, and when the cognitive environment is influential, the use non-coercive power is preferred. This paper provides new insights into research of channel environment, and also provides practical guidance and suggestions for channel member decision makers.
\end{abstract}

Keywords: Channel task environment, Channel institutional channel, Use of power, Channel satisfaction

\section{Introduction}

Gordon Moore, the founder of Intel once said, technology of silicon chip involves every 18 months. And in 2015, fifty years after the prediction, Nature proclaimed that in semiconductor industry, the Moore Law may appear invalid, but the generalized Moore Law is working almost in every industry, especially in developing countries such as China, where economy develops rapidly, industrial revolution and upgrading take place frequently, which make the channel task environment more dynamic and complex.

Task environmental change is not the only change companies are facing, institutional environment is also involving rapidly. As business and economic laws come into effect, the legal system has enforced huge influence on corporation management. Besides, regulators, such as industrial and commercial bureau, are also keeping an eye on business operation. Meanwhile, special cultures, norms and customs in China, such as "Guanxi", are also having invisible while important impact on channel management.

However, in the field of channel behavior, researchers paid more attention to intra-channel antecedent factors such as power balances (Frazier, 1983), dependency (Heide, 1994) and dyadic sentiment (Dwyer et al., 1987), and overlooked the influence of channel environment on members' behavior (Stern \& El-Ansary, 1992; Weitz \& Jap, 1995; Geyskens, Steenkamp \& Kumar, 1999; Grewal \& Dharwadkar, 2002). The few papers which noticed the influence of channel environment, focused on one task environment variable "Uncertainty"(Dess \& Beard, 1984; Boyd, 1990, 1995; Bluedorn, 1993; Carpenter \& Fredrickson, 2001), and still neglect other dimensions of task environment and institutional environment (Grewal \& Dharwadkar, 2002). Therefore, a systematic analysis of how task and institutional channel environment influence channel behavior is necessary.

This study explores the relationship of channel environment, use of power and channel satisfaction, which is composed of two parts: channel environment $\rightarrow$ channel members' use of power $\rightarrow$ channel relational quality. This study attempts to answer the following three questions: first, how does task environment influence channel members' use of power? Secondly, how does institutional environment influence channel members' use of power? Thirdly, how does the channel members' behavior of power use affect channel satisfaction?

The rest of the paper first discuss relevant literature, summarize and analyze the relationship of the variables, and put forward the conceptual framework, and theoretical hypotheses. Secondly state the empirical methodology, including questionnaire design, data collection, reliability and validity test. Thirdly, summarize the results of empirical analysis. Last, evaluate and interpret the implications, draw inferences and conclusions from the results. 


\section{Relevant Literature and Theoretical Framework}

\subsection{Relevant Research}

Etgar (1977) proposed that internal behavior, relationship and structure within a channel are affected by the environmental characteristics and factors. Channel members have to adjust channel behavior according to external environment, and develop a more appropriate strategy, so as to adapt to the environment, which is vital for survival and development in specific environment. However, channel researchers pay more attention to internal factors, such as the distribution of economic and social resources between channel members (Frazier \& Summers, 1984; Gundlach \& Carotte, 1994; Payan \& McFarland, 2003), power structure and status (Frazier et al., 1989; Frazier \& Summers, 1984), transaction specific investment (Joshi \& Stump, 1999; Frazier, Sawhney \& Shevani, 1999), channel relational quality, such as channel trust commitment (Dwyer, Schurr \& Oh, 1987), channel relationship the strength, such as the degree of intimacy and mutuality (Stanko, Bonner \& Clantone, 2007; Gilliland \& Bello, 2002), channel state (Anderson \& Narus, 1990; Mohr \& Nevin, 1990),etc.. However, the influence of channel environment on channel operation process and results has been largely neglected and underestimated (Etgar, 1977; Anchrol et al., 1983; Grewal \& Dharwadkar, 2002).

Kotler (2000) put forward that channel environment is composed of all factors that has direct or indirect, explicit or invisible influence on channel operation, which can be divided into macro and micro environment. The macro environment includes political, economic, technological, cultural and natural factors, which indirectly affect channel operation. While micro environment refers to the sum of supplier, distributor, customer and competitor, which have a direct influence on channel members. Although the definition and deconstruction are comprehensive and systematic, it's hard to measure and assess. Therefore, relevant empirical studies rarely take this perspective.

Empirical studies of channel environment extract measurable dimensions, such as environmental uncertainty, which refers to environment volatility and unpredictability of environmental changes. Environmental uncertainty has been taken as an important antecedent of channel behavior (Anchrol et al., 1983; Boyd, et al., 1990, 1995; Bluedorn, 1993; Carpenter \& Fredrickson, 2001; Grewal \& Dharwadkar, 2002; Zhou \& Poppo, 2010; Sheng et al., 2011). In a highly uncertain environment, it's impossible to obtain sufficient information to assess the relationship between environmental factors and their results (Child, 1972), which leads to high level of information asymmetry, opportunistic and operational risk (Williamson, 1989; Heide \& Steenkamp, 1994). Channel members rely on frequent use of interactive communication to obtain more information, conduct informal coordination to flexibly adjust to environmental (Meyer \& Rowan, 1977; Scott, 1987). Etgar (1977) used four dimensions to describe channel environment: growth of demand, stability of demand, complexity of operation, and competition intensity. His study pointed out that when demand is growing rapidly or unstable, channel members would employ flexible control mechanism to stay creative and quick-responsive, while centralization is preferred when demand slows down or stable (Guiltinan \& Joseph, 1974; Guiltinan \& Joseph, 1974). In an environment where operation involves few factors and elements, channel members tend to use standardization and procedural control method, while flexible control mechanism is preferred in a complex operation environment. In a highly competitive environment, channel members pursue maximum efficiency, thus centralization and high level of control would be often employed. Aldrich (1974) described a framework of six organizational environmental dimensions: environmental capacity, environmental homogeneity, environmental stability, environmental stability, environmental concentration, environmental turbulence, and domain consensus. Achrol, Reve and Stern (1983) modified Aldrich's framework, put forward a seven-dimension framework, and applied it to channel scenario, including environmental capacity, environmental homogeneity, environmental stability, environmental stability, environmental concentration, environmental turbulence, environmental dependency and environmental conflict. Wu (2006) explored the relationship of the seven environmental dimension and channel conflict as well as channel cooperation, and found out that environmental capacity decreases channel conflict and promote cooperation, environmental dependency leads to channel conflict, while channel dynamism enhances channel cooperation. However, these studies only take task environment into consideration and neglect the impact of institutional environment.

As new institution theory rise, institutional analysis paradigm has become an important perspective of organizational research (Zuker, 1983; DiMaggio, 1988; Scott, 1987, 1994). Grewal and Dharwadkar (2002) proposed that the institutional environment consists of three dimensions, regulatory environment, normative and cognitive environment, which influence channel members' behavior respectively through government agencies, industry associations and cultural traditions. Yang, Su and Fam (2012) used a Chinese sample of manufacturers that export product to various foreign markets through local distributors, developed and tested a model that bridges the effects of institutional environments and governance strategy on channel performance, and found that firms can use two 
governance strategies, contract customization and relational governance, to deal with both legitimacy and efficiency issues and to safeguard channel performance. Jia and Wang (2013) explored the relationship of institutional environment on government Guanxi, interfirm Guanxi and interpersonal Guanxi, developed a set of propositions focusing on issues such as Guanxi, trust and dependence from an institutional perspective. Guo (2013) pointed out that relational governance method, such as co-planning and co-solving problems are influenced by task and institutional environment characteristics.

Previous studies about channel environment only focused on one perspective, either task environment or institutional environment, or didn't combine those two views to systematically analyze the influence of channel environment. Besides, the relationship of channel environment and governance strategies, such as contractual and relational governance was analyzed, while the relationship of channel environment and use of power still remains unclear.

\subsection{Conceptual Background}

Chanel Environment: Marketing channel is "a set of interdependent organizations participating in the process of making a product or service available for use or consumption" (Kotler, 2000). In the most common scenario, marketing channel refers to the system composed of manufacturer and distributors (El-Ansary et al., 2000), and channel environment exists outside of the boundary of the binary relationship (Zhang, 2007). Economics theories point out that channel environment is composed of all factors directly influential to goal setting and attainment (Dill, 1958; Penrose, 1959). However, sociology perspective takes into consideration more macro factors into this concept, such as political, social and cultural environment (Scott, 1992). Daft (1998) combined two perspectives and put forward that external factors existing outside the channel boundary and having direct or indirect impact on organization, are all environmental factors.

Channel environment can be divided into two dimensions, task environment and institutional environment (DiMaggio and Powell, 1983), corresponding to the two perspectives of economics and sociology. Channel members pursue two goals: economic and social goals. Economic goals stress the significance of task environment, and underscore economic efficiency, while social goals emphasize the importance of institutional environment, and pursue legitimacy (Scott, 1987; Oliver, 1991). Table 1 shows the difference between the two types of environments.

Most previous empirical research of organizations focused on task environment, which has been recognized as the environment that directly influences organizations (Scott 1983), specifically, Scott (1981) points out that task environments can be reduced to major groups of actors: customers of the output, suppliers of the input, and competitors. Most organizational theories acknowledge that the task environment can be divided into multiple dimensions (Boyd, 1995), and the most acknowledged dimensions are dynamism, complexity and munificence (Castrogiovanni, 1991; Bluedorn, 1993; Carpenter\& Fredrickson, 2001). Dynamism refers to the unpredictability of environmental change (Dess \& Beard, 1984) and the degree of interconnection between different elements (Aldrich, 1979). Complexity suggests whether the environment is concentrated or disperse, and describes the heterogeneity and the range of the organizations activities in the task environment (Keats \& Hitt, 1988). Castrogiovanni (1991) defines munificence as the abundance of needed resources that companies could get from the environment. Thus, munificence refers to the capacity and ability of environments for organizations to grow (Aldrich, 1979). Researches proved that dimensions of task environment are all influential factors to organization behaviors (Koberg, 1987; Irwin et al., 1998; Zyglidopoulos \& Stelios C, 2007).

However, economic efficiency perspective has ignored the impact of macro-environment and social context, unlike the task environment approach, institutional approach focuses on organizational legitimacy of social stakeholders (Granovetter, 1985).

Institutional environment consists of three dimensions from the perspective of legitimacy sources (DiMaggio \& Powell, 1983; Suchman, 1995). Regulatory environment uses political or legal system and mechanism to force channel members to behave in certain ways. Regulatory environment includes government, law system and other regulatory mechanism, and emphasizes pragmatic legitimacy concerns (Kelman, 1987). Normative environment refers to trade associations, professional agencies and other industrial traditions and customs. Normative institutions stresses procedural legitimacy concerns (Selznick 1984). Cognitive environment includes social values, beliefs and norms that exert subtle, invisible yet vital influence on channel behaviors, which are associated with cognitive legitimacy concerns (Berger \& Luckmann, 1967).

Compared to developed countries, developing countries' institutional environment is more important (Farashahi, Mehdi, Hafsi, et al., 2005), especially in China, where special political, economic and cultural environment is more influential. Therefore, institutional environment may play a more important role in China (Renxingyao et al., 2010). 
Table 1. Institutional VS. Task environment perspectives

\begin{tabular}{lll}
\hline & Task environment & Institutional environment \\
\hline Channel character & Economic system & Social system \\
Environmental context & Market & Social, political and cultural \\
Demand factor & Resources & Legitimacy \\
Pressure & Competitive & Coercive, mimetic, normative \\
Constituents & Agencies, associations and norms & Source of needed factors \\
Mechanism of control & Rules, regulations, inspections & Exchange dependencies \\
Success factor & Conformity to rules and norms & Control of critical resources \\
\hline
\end{tabular}

Christine Oliver. The Influence of Institutional \& Task Environment Relationship on Organizational Performance. The Canadian Construction Industry, 1997, 34(1): 99-110

Use of power: Power can be defined as the sense of control and the perception that one can influence outcomes (Uhl-Bien \& Carsten, 2007). One of the most important sources of organizational power is the coercive power which is defined as the ability to influence others by using threats, punishments or sanctions. In an organizational setting, this source of power can be used to control the employees and to ensure that their actions are in line with organizational objectives (Riasi \& Asadzadeh, 2015, 2016).

Channel members use power to change the attitudes and behaviors of the counterparts (Mohr \& Nevin, 1990). The six generally acknowledged powers are, legalistic pleas, threats, promises, requests, recommendations and information exchange (Frazier \& Summers, 1986; Frazier and Rody 1991; Boyle et al., 1992). These six strategies were further divided into two groups, coercive power and non-coercive power (Frazier \& Summers, 1986; Frazier \& Rody, 1991).

The use of coercive power forces channel partners to behave in certain ways and comply with certain rules, on the basis of threatening to punish or not reward them. While the use of non-coercive power influences channel partners by changing their attitudes and intentions (Payan \& McFarland, 2005).

Channel satisfaction: Channel members' satisfaction is defined as a positive affective state because of behaviors, relationships with their counterparts (Frazier et al., 1989). Channel satisfaction is a fundamental concept of channel relationships (Ruekert \& Churchill, 1984).

Satisfaction constitutes of two dimensions: economic and non-economic satisfaction (Gassenheimer et al., 1994). Economic satisfaction refers to the positive state resulting from financial rewards benefited from the channel relationship, such as revenue, sales volume (Dwyer \& Gassenheimer, 1992). While non-economic satisfaction is because of psychosocial reasons in the interaction with his channel partner, such as gratifying and fulfilling (Mohr et al., 1996)

\subsection{Theoretical Framework and Research hypotheses}

Our conceptual framework, summarized in Figure 1, is a two-part model aimed at understanding the following relationships: channel environment $\rightarrow$ channel members' use of power $\rightarrow$ channel relational quality. H1-H6 describe the relationships of the first part of our model, which analyze the influence of each factor of channel environment on use of power. $\mathrm{H} 7$ and $\mathrm{H} 8$ elaborate on the second part of our model, which focus on the influence of channel members' use of power on channel non-economic satisfaction.

As stated by Buchko (1994), in dynamic and complex environments, firms try to adopt more flexible processes, in order to minimize the risk and negative influence brought by information asymmetry (Ouchi, 1980). The lack of information calls for frequent interactive communication and information exchange (Meyer \& Rowan, 1977). Koberg (1987) suggests that frequency of information exchange is related to the perceived environmental uncertainty. Tushman and Romanelli (1985) also found that management style of companies in uncertain environment tend to be more flexible and loose. Brown and Eisenhardt (1997) also proved that companies exchange information more frequently in velocity environment. Besides, the difficult situation enhances a sense of solidarity as a community, which helps establish common vision and values. The emotional bond encourages reciprocal behaviors, and prohibits compulsive behaviors (Beckman et al., 2004). 
H1: Suppliers tend to use non-coercive power in a dynamic environment.

H2: Suppliers tend to use non-coercive power in a complex environment.

Aldrich (1979) found that companies conduct cutthroat practices in lean environment, and were rewarded for its efficiency. Therefore, companies are cultivated to develop a short-term vision, which encourages focusing on efficiency and neglecting other factors, therefore, they tend to treat the counterparts without consideration of long-term cooperation (Zyglidopoulos, 1999). Thus, the level of munificence is negatively related to the use of coercive power.

H3a: Suppliers tend not to use coercive power in a munificent environment.

However, there's also proof supporting the opposite correlation: in a munificent environment, it's more convenient and easier for channel members to seek and obtain vital resources, which leads to less dependency on channel partners, lower cost of losing them and greater likelihood to find new ones (Goll .I \& Rasheed A.,2004).

H3b: Suppliers tend to use coercive power in a munificent environment.

In an environment where regulatory systems and institutions are sufficiently powerful to impose constraints and orders, the use of legalistic pleas is guaranteed with its power (Joskow, 1985). On the contrary, if regulatory institutions are not influential, they are unable to provide valued impact on channel partners, and the legalistic pleas would be difficult to implement without strong legal support (Williamson, 1991).

H4: Suppliers tend to use coercive power when the regulatory environment is influential.

Influential normative environment comes with a greater presence of authorization mechanisms, such as industrial associations, companies tend to exchange ideas about channel management practices more frequently, which leads to high level of participation, consensus building (Dwyer et al., 1987; Meyer \& Scott, 1992), and homogenized standards in an industry (DiMaggio \& Powell 1983; Scott et al., 1987)

H5: Suppliers tend to use non-coercive power when the normative environment is influential.

Cognitive environment promote informal mechanism as a substitute for formal coordination and control behaviors, which contribute to long-term cooperation and bonding (Ouchi 1980). As a result, members would not resort to coercive power to solve problems and come to an agreement (Gundlach and Cadotte 1994). Therefore, powerful cognitive mechanism encourages non-coercive strategy and prohibits coercive strategy implementation (Kumar et al., 1995).

H6: Suppliers tend to use non-coercive power when the cognitive environment is influential.

Use of coercive power leads to tension and frustration (Lusch and Brown 1982), and it's perceived as an exploitation, or even abuse of power advantage (Schurr \& Ozanne, 1985). Besides, the intention of control other's behaviors by impulsive power results in psychological reactance and revolt (Provan \& Skinner, 1989), which may lead to actual retaliation and opportunism (Venkatesh eta al., 1995).

H7: The use of coercive power is negatively related to channel non-economic satisfaction.

The use of coercive power offers a higher value for channel partners with helpful market information, suggestions and professional training (Gaski, 1984), which promote the welfare of channel partners, and help counterparts get out of an adverse situation or obtain competition advantage (Raven \& Kurglanski, 1970; Kasulis \& Speckman, 1980), therefore, economic satisfaction is effectively promoted (Angelmar \& Stern, 1978).

H8: The use of non-coercive influence power is positively related to channel economic satisfaction.

Use of non-coercive power influences channel members based on rational persuasion (Frazier \&d Sheth, 1985; Bhatnagar, 1993), which leads to perception of mutual respect and benefit, and promote satisfaction (Kasulis \& Spekman, 1980). In addition, it helps developing and strengthening beliefs and attitudes that channel members share common objectives and values (Bonoma 1976).

H9: The use of non-coercive power is positively related to channel non-economic satisfaction. 


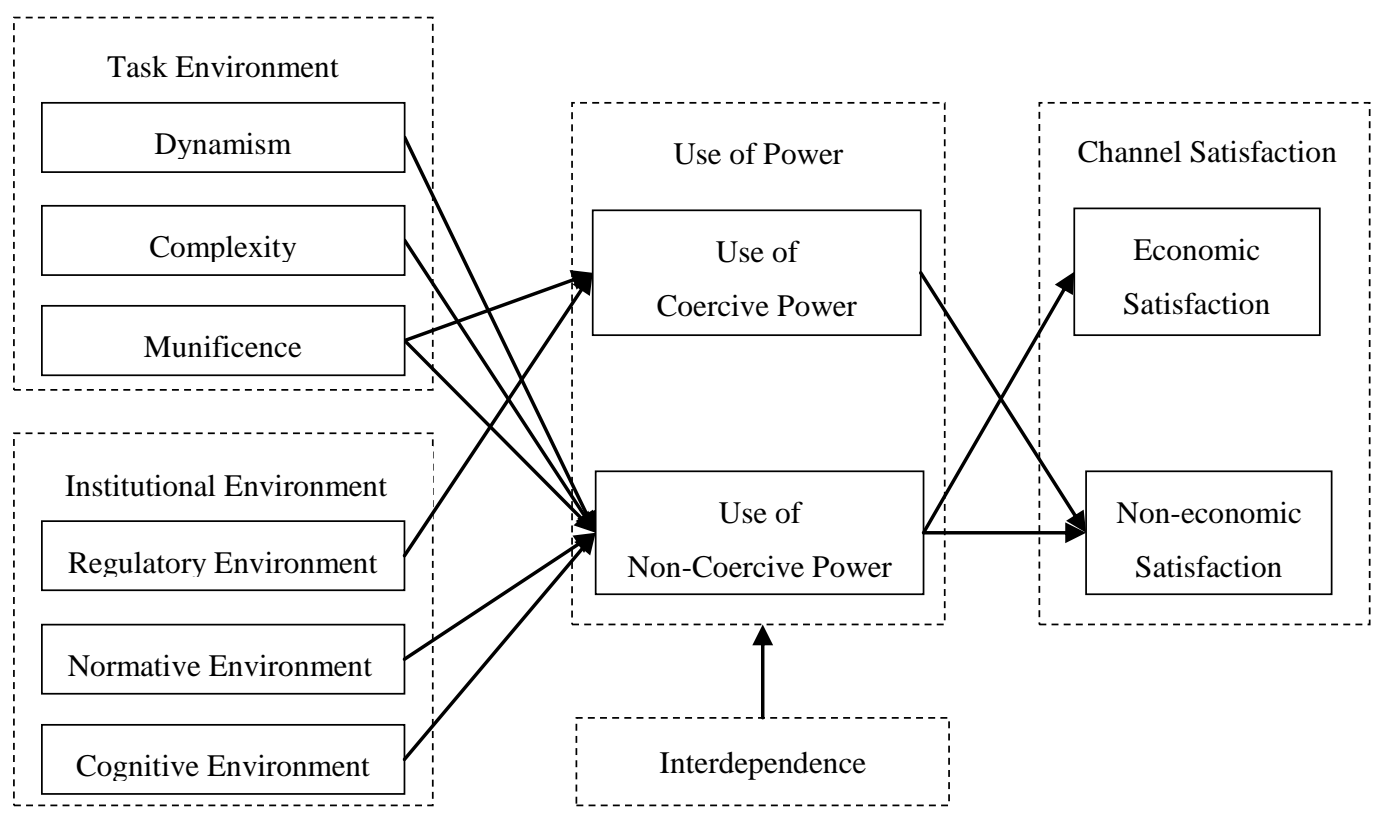

Figure 1. Theoretical Framework

\section{Method}

\subsection{Data Collection}

We test the hypotheses using a sample of distributors of a large-scale petrochemical enterprise. We choose respondents in petrochemical industry for two reasons: firstly, this industry is strictly regulated and influenced deeply by industry associations and norms, which is suitable for our research to analyze the impact of institutional environment. Secondly, this industry is going through big changes because of the technological revolution of automobiles, such as electric vehicles, therefore the influence of task environment is significant.

Before sending out formal questionnaires, we communicated with managers of Sinopec, and set a standard for stratified sampling to balance numbers of distributors of different sizes, provinces and organization forms. According to Benter and Chou (1987), in empirical study using factor analysis, the minimum sample size is three times the number of relevant parameters. Taking research requirements and actual situation into consideration, we picked 400 gas stations as respondents, and communicated with them about the objectives instructions of this survey, and mailed out questionnaires. Out of the 400 respondents, 259 sent back their answers, and 221 validated questionnaires are collected overall, the validated response rate of $55.3 \%$.

Of all the respondents, $71 \%$ are general managers of gas stations, and $15 \%$ are operational managers; $77 \%$ have worked in gas stations for at least 3 years, which suggest that the respondents know well about the cooperation and relationship with Sinopec. Of all the sample gas station, $48 \%$ are in Jiangsu Province, 25\% are in Hunan Province, and the ones in Hebei and Guagndong Provinces both take up for more than 12\%; 25\% have been cooperated with Sinopec for at least 10 years, $43 \%$ for 5 to 10 years, and $32 \%$ for less for 5 years, which suggest that the sample is highly diversified and not biased.

\subsection{Measures}

Questionnaire was designed to collect data from Sinopec distributors (gas stations). First, we established research framework and constructs, and developed a set of measure on the basis of literature. Secondly, we communicated with representatives of distributors, and revised the measure according to the industrial context. Then, we made modification after a pilot study.

The questionnaire was designed in Likert five-point scale. Respondents were asked to pick and answer from "1" (totally disagree) to "5" (totally agree) with respect to the statements. Measures of related constructs are as below:

Dynamism: In local market, technology updates rapidly; consumer demands and preferences constantly change; 
changes in the environment are difficult to predict (Dess \& Beard, 1984).

Complexity: In local market, the marketing environment is very complex; consumer demand is influenced by many factors; sales are influenced by many factors (Dess \& Beard, 1984).

Munificence: Oil is in great demand; there are few competitors; the overall sales situation is satisfactory (Dess \& Beard, 1984).

Regulatory environment: local government severely punishes violations of laws and regulations; government protects the interests of market players through strict law enforcement; government drives companies to abide by laws and regulations; government responds swiftly to regulation violation (Grewal \& Dharwadkar, 2002; Zhang, 2003).

Normative environment: companies learn industry standards from professional associations; companies abide by industrial norms; whether to abide by the industrial norm has strong influence on enterprise operation; the public appreciate that stakeholders are treated well (Grewal \& Dharwadkar, 2002; Hyun, 2001).

Cognitive environment: local culture influences channel construction and management; local values and unwritten norms influence channel management; companies comply with local conventions and traditions; local traditions and customs influence channel management (Grewal \& Dharwadkar, 2002; Mcfarland, 2003).

Coercive strategy: suppliers claim that they'll terminate partnership and dealership if we don't comply with their requirements; suppliers claim that we won't get favorable discount if we don't comply with their requirements; suppliers claim that they'll take it to court if we don't comply with their requirements (Stern L. W. \& EI-Ansary, 1972; Boyle et al., 1992; Soumava \& Robicheaux, 1998).

Non-coercive strategy: Suppliers offer us effective business suggestions; suppliers provide much market information; suppliers inform us about competitors; suppliers offer us training (Stern \& EI-Ansary, 1972; Boyle et al., 1992; Soumava \& Robicheaux, 1998).

Economic satisfaction: we are satisfied with achievements of sales; with return on investment; with sales growth (Cannon \& Perreault, 1999; Mayo et al., 1998)

Non-economic satisfaction: we are satisfied with credibility and reliability of the supplier; with service attitude of the supplier; with effective communication and timely response; with the ability of solving problems (Ruekert \& Churchill, 1984; Geyskens \&Steenkamp, 2000)

\subsection{Reliability and Validity Tests}

A reliability analysis using Cronbach's alpha and composite reliability index were performed to ensure the internal consistency of the items that constitute each construct, the results are as shown in Table 3 (Cronbach, 1951; Fornell \& Larcker, 1981). The table shows the values of Cronbach's alpha and CR for each of constructs all exceed 0.7, indicating a good internal consistency and reliability of the constructs.

Then, we used explanatory factor analysis to identify a possible underlying factor structure. The factor solutions confirmed our expectations, all items had factor loadings that exceeded the recommended level of 0.5 (Hair et al., 1998), and none of the items cross-loaded on multiple factors. We can safely conclude that constructs are dissimilar constructs.

In addition, we analyzed all measures in a single confirmatory factor analysis model, and all items loaded significantly on their corresponding latent factors, with coefficients above 0.5 , indicating good convergent validity.

Furthermore, we ran a test to assess the discriminatory validity. As we can see from Table 2, average variance extracted (AVE) values, are all above 0.5 , indicating good discriminatory validity. 
Table 2. Reliability and validity tests

\begin{tabular}{|c|c|c|c|c|}
\hline Constructs & $\mathrm{CR}$ & Cronbach's alpha & AVE & Factor loading \\
\hline \multirow{3}{*}{ Dynamism } & \multirow{3}{*}{0.9674} & \multirow{3}{*}{0.954} & \multirow{3}{*}{0.8} & 0.939 \\
\hline & & & & 0.935 \\
\hline & & & & 0.748 \\
\hline \multirow{3}{*}{ Complexity } & \multirow{3}{*}{0.8652} & \multirow{3}{*}{0.845} & \multirow{3}{*}{0.6} & 0.883 \\
\hline & & & & 0.821 \\
\hline & & & & 0.77 \\
\hline \multirow{3}{*}{ Munificence } & \multirow{3}{*}{0.9186} & \multirow{3}{*}{0.906} & \multirow{3}{*}{0.7} & 0.842 \\
\hline & & & & 0.876 \\
\hline & & & & 0.894 \\
\hline \multirow{4}{*}{$\begin{array}{l}\text { Regulatory environment } \\
\text { (RE) }\end{array}$} & \multirow{4}{*}{0.9425} & \multirow{4}{*}{0.938} & \multirow{4}{*}{0.88} & 0.883 \\
\hline & & & & 0.909 \\
\hline & & & & 0.912 \\
\hline & & & & 0.882 \\
\hline \multirow{4}{*}{$\begin{array}{l}\text { Normative environment } \\
\text { (NE) }\end{array}$} & \multirow{4}{*}{0.9198} & \multirow{4}{*}{0.920} & \multirow{4}{*}{0.68} & 0.921 \\
\hline & & & & 0.857 \\
\hline & & & & 0.788 \\
\hline & & & & 0.839 \\
\hline \multirow{4}{*}{$\begin{array}{l}\text { Cognitive environment } \\
\text { (CE) }\end{array}$} & \multirow{4}{*}{0.9316} & \multirow{4}{*}{0.935} & \multirow{4}{*}{0.7} & 0.86 \\
\hline & & & & 0.864 \\
\hline & & & & 0.847 \\
\hline & & & & 0.808 \\
\hline \multirow{3}{*}{$\begin{array}{l}\text { Coercive Power } \\
\text { (CP) }\end{array}$} & \multirow{3}{*}{0.7807} & \multirow{3}{*}{0.75} & \multirow{3}{*}{0.53} & 0.636 \\
\hline & & & & 0.806 \\
\hline & & & & 0.703 \\
\hline & & & & 0.672 \\
\hline Non-coercive Power & 09157 & 0852 & 064 & 0.743 \\
\hline$(\mathrm{NCP})$ & ל ו & & & 0.89 \\
\hline & & & & 0.744 \\
\hline Fonnomic coticfoction & & & & 0.819 \\
\hline Economic satistaction & 00702 & 0020 & 070 & 0.882 \\
\hline (ES) & $0.0 / 25$ & 0.059 & 0.10 & 0.612 \\
\hline & & & & 0.846 \\
\hline & & & & 0.858 \\
\hline Non-economic satisfaction & 08012 & 0001 & 07 & 0.77 \\
\hline (NES) & 0.0912 & 0.901 & 0.1 & 0.864 \\
\hline & & & & 0.847 \\
\hline
\end{tabular}




\subsection{Model Estimation Method}

This study builds a structural equation model (SEM) to estimate the theoretical model and test the research hypotheses. Structural equation modeling is a multivariate statistical framework that is used to model complex relationships between directly and indirectly observed (latent) variables. SEM involves simultaneously systems of equations and encompasses other techniques such as regression, factor analysis, path analysis and latent growth curve modeling.

Since the method of collecting data with questionnaire attempt to get respondents' overall opinion of each latent variable (constructs) with several relevant observed variables (items), the method of SEM is the most suitable method for model estimation with data collected via questionnaire survey. In social science domain, the method of SEM is widely used to bridge causal hypotheses and survey data, to reveal relationship of all latent variables (constructs) from an overall perspective.

In this study, we use statistical software R and its package SEM and LAVAAN to estimate the theoretical model.

\section{Empirical Results}

The fitness of this structural equation model is good, as we can see from Table, $3, \chi^{2} / \mathrm{df}=1.68$, below the recommended level of 5, CFI and TLI index are all above the recommended level of 0.9 (Bentler, 1987), RMSEA and SRMR are separately below their recommended level of 0.1 and 0.08 (Steiger, 1990).

Table 3. Empirical results

\begin{tabular}{|c|c|c|c|c|c|}
\hline \multicolumn{2}{|c|}{ Hypotheses } & Relationships & Coefficients & T value & Results \\
\hline \multirow[t]{3}{*}{ Task environment } & H1 & Dynamism $\rightarrow \mathrm{NCP}$ & $0.749 * *$ & 2.857 & + \\
\hline & $\mathrm{H} 2$ & Complexity $\rightarrow \mathrm{NCP}$ & 0.188 & 1.295 & n.s. \\
\hline & H3 & Munificence $\rightarrow \mathrm{CP}$ & $0.410 *$ & 1.980 & + \\
\hline \multirow{3}{*}{$\begin{array}{l}\text { Institutional } \\
\text { environment }\end{array}$} & $\mathrm{H} 4$ & $\mathrm{RE} \rightarrow \mathrm{C}$ & $0.746 * *$ & 2.853 & + \\
\hline & H5 & $\mathrm{NE} \rightarrow \mathrm{NCP}$ & 0.279 & 1.758 & n.s. \\
\hline & H6 & $\mathrm{CE} \rightarrow \mathrm{NCS}$ & $0.514 *$ & 2.113 & + \\
\hline \multirow[t]{4}{*}{ Use of Power } & $\mathrm{H} 7$ & $\mathrm{CP} \rightarrow \mathrm{NES}$ & $-0.865^{* * *}$ & -2.899 & - \\
\hline & $\mathrm{H} 8$ & $\mathrm{NCP} \rightarrow \mathrm{ES}$ & $0.359 *$ & 2.319 & + \\
\hline & H9 & $\mathrm{NCP} \rightarrow \mathrm{NES}$ & $0.611 * *$ & 2.270 & + \\
\hline & & Dependence on distributor $\rightarrow \mathrm{CP}$ & 0.125 & 1.18 & \\
\hline \multirow{3}{*}{\multicolumn{2}{|c|}{ Control variables }} & Dependence on distributor $\rightarrow \mathrm{NCP}$ & 0.103 & 1.007 & \\
\hline & & Dependence on supplier $\rightarrow \mathrm{CP}$ & $0.611^{* *}$ & 2.113 & \\
\hline & & Dependence on supplier $\rightarrow \mathrm{NCP}$ & $0.579 * *$ & 2.252 & \\
\hline \multirow{7}{*}{\multicolumn{2}{|c|}{ Model fitness }} & $\chi^{2}$ & 1168.045 & & \\
\hline & & $\mathrm{df}$ & 692 & & \\
\hline & & $\chi^{2} / \mathrm{df}$ & 1.68 & & \\
\hline & & CFI & 0.963 & & \\
\hline & & TLI & 0.978 & & \\
\hline & & RMSEA & 0.054 & & \\
\hline & & SRMR & 0.073 & & \\
\hline
\end{tabular}

***: Significant at the 0.001 level; **: Significant at the 0.01 level; *: Significant at the 0.05 level.

As we can see from Table 3, H1, H3b, H4, H6, H7, H8 and H9 are all supported by the empirical results.

Task environmental dynamism and munificence are influential to use of power. Suppliers tend to use non-coercive power in a dynamic environment. Due to lack of information, suppliers prefer non-coercive power such as information exchange and suggestion to reduce the risk of uncertain environment. Suppliers tend to use coercive power in a munificent environment, since the cost of losing channel partners decreases, which leads to overuse of 
coercive power.

Institutional environment also has a huge impact on the use of influence power, especially in regulatory and cognitive environment. Suppliers tend to use coercive power when the regulatory environment is influential, since regulatory environment provides a fundamental system for channel members to use coercive power such as legalistic pleas. Besides, suppliers tend to use non-coercive power when the cognitive environment is influential. Cognitive environment facilitates the evolution of informal mechanism which leads to long-term bonding and cooperation of channel partners, as a result, channel members don't need to resort to coercive power to resolve problems.

In addition, this study also analyzes the relation between use of power and channel satisfaction. We find that the use of coercive power is negatively related to channel non-economic satisfaction. Meanwhile, the use of non-coercive power is positively related to both economic and non-economic satisfaction.

\section{Conclusion and Discussion}

This study builds a structural equation model to explore the relationship of channel environment, use of power and channel satisfaction, which is composed of two parts: channel environment $\rightarrow$ channel members' use of power $\rightarrow$ channel relational quality.

This study successfully answers the three questions stated in the beginning: first, about the corresponding reaction to specific task environment: suppliers tend to use non-coercive power in a dynamic environment and coercive power in a munificent environment; secondly, about the corresponding reaction to specific institutional environment: suppliers tend to use coercive power when the regulatory environment is influential and tend to use non-coercive power when the cognitive environment is influential; thirdly, about the influence of channel members' use of power on the level of channel satisfaction: the use of coercive power is negatively related to channel non-economic satisfaction, while the use of non-coercive power is positively related to both economic and non-economic satisfaction.

This study systematically analyzes the relation between external channel environment and use of power. And empirical research with data collected from Sinopec distributors suggests that, both task and institutional environment are influential to use of power, specifically, environmental dynamism, as well as institutional cognitive pressure urge channel members to employ non-coercive strategy, while environmental munificence, as well as institutional regulatory pressure prompt the use of coercive power.

Theoretical contributions: this study contribute to the marketing channel research in three ways: first, this paper proves that the overlooked concept, channel environment, has a huge impact on behaviors of channel members; second, this paper takes every dimension of external environment into consideration, specifically, and systematically analyzes their influence; third, this paper combined theories from different domains, such as institutional theory from organizational sociology, task environment from economics, influence strategy from social exchange theory and social psychology.

Managerial implications: this study offers multiple implications to marketing practice: first, channel decision makers should take a contingency perspective to adjust strategy along with the change of channel external environment; second, environment is composed of both task and institutional environment, which can be further divided into more specific dimensions, and the different dimensions influence channel behavior in different ways, channel members should scan every aspect of environment and pay attention to the influential ones; third, use of coercive power deteriorates channel relation while use of non-coercive power improves relationship quality. If supplier aims to maintain a good relationship with distributors, use coercive strategy as less as possible.

Limitations and future study: first, data was collected from one side of the dyadic relation, which may lead to bias, future studies may consider collecting data from both suppliers and manufactures; second, this study explores correlations in channel of petroleum industry, future studies may consider diversifying the data sources and collect data from multiple industries.

\section{Acknowledgements}

The author appreciates the generous financial support from the National Science Foundation of China for Projects No. 71372046. 


\section{References}

Angelmar, Richard \& Louis Stem. (1978). Development of a Content Analytic System for Analysis of Bargaining Communication in Marketing. Journal of Marketing Research, 15(2), 93-102. https://doi.org/10.2307/3150404

Carpenter, M. \& Fredrickson, J.. (2001). Top management teams, global strategic posture, and the moderating role of uncertainty . Academy of Management Journal, 44, 533-45. https://doi.org/10.2307/3069368

El-Ansary, Adel I, \& Louis W. Stern. (1992). Marketing channels. Prentice-Hall,.

Frazier G L, Gill J D, Kale S H. (1989). Dealer dependence levels and reciprocal actions in a channel of distribution in a developing country . The Journal of Marketing, 65, 50-69. https://doi.org/10.2307/1251524

Geyskens I, Steenkamp J B E M, N. (1999). A meta-analysis of satisfaction in marketing channel relationships . Journal of marketing Research, 36(2), 223-238. https://doi.org/10.2307/3152095

Keats, B. \& Hitt, M. (1988). A causal model of linkages among environmental dimensions, macro organizational characteristics, and performance . Academy of Management Journal, 31(3), 570-98. https://doi.org/10.2307/256460

Porter, Michael E. (1980). Competitive Strategy: Techniques for Analyzing Industries and Competitors. New York: Free Press, 852-891.

Scott W R. (1987). The adolescence of institutional theory. Administrative science quarterly, 32(4), 493-511. https://doi.org/10.2307/2392880

Stern, L. W, A. I. El-ansary, A. T. (1996). Coughlan. Marketing Channels. Upper Saddle River, NJ: Prentiu-hall.

Dess G G, Beard D W. (1984). Dimensions of organizational task environments . Administrative Science Quarterly, 29, 52-73. https://doi.org/10.2307/2393080

Dimaggio P J, Powell W W. (1983). The iron cage revisited: Institutional isomorphism and collective rationality in organizational fields. American Sociological Review, 48(2), 147-160. https://doi.org/10.2307/2095101

Dwyer, F.R., P.H. Schurr, \& S. Oh. (1987). Developing buyer- seller relationships. Journal of Marketing, 51(April), 11-28. https://doi.org/10.2307/1251126

Grewal, Rajdeep, Ravi Dharwadkar. (2002). The Role of the Institutional Environment in Marketing Channels. Journal of Marketing, 66(3), 82-97. https://doi.org/10.1509/jmkg.66.3.82.18504

Heide, J. B. (1994). Inter-organizational Governance in Marketing Channels. Journal of Marketing, 58(1), 71-85. https://doi.org/10.2307/1252252

Kotler Philip. (2000). Marketing Management. Englewood Cliffs, NJ:Prentice-Hall,Inc.

Ouchi W G. (1980). Markets, bureaucracies, and clans. Administrative science quarterly, 129-141. https://doi.org/10.2307/2392231

Bagozzi RP, Edwards JR. (1998). A general approach for representing constructs in organizational research. Organizational Research Methods, 1, 45-87. https://doi.org/10.1177/109442819800100104

Beckman, Christine, Pamela Haunschild, \& Damon Phillips. (2004). Friends or Strangers? Firm-Specific Uncertainty, Market Uncertainty, and Network Partner Selection. Organization Science, 15(3), 259-275. https://doi.org/10.1287/orsc.1040.0065

Bentler P M, Chou C P. (1987). Practical issues in structural modeling. Sociological Methods and Research, 16(1), 78-117. https://doi.org/10.1177/0049124187016001004

Bergen, Mark, Shantanu Dutta, \& Orville C, Walker. (1992). Agency Relationships in Marketing: A Review of the Implica- tions and Applications of Agency and Related Theories. Journal of Marketing, 56(7), 1-24. https://doi.org/10.2307/1252293

Boyle B, Dwyer F R, Robicheaux R A. (1992). Influence strategies in marketing channels: Measures and use in different relationship structures. Journal of Marketing Research, 29(4), 462-474. https://doi.org/10.2307/3172712

Castrogiovanni, G. (1991). Environmental munificence: a theoretical assessment. Academy of Management Review, 16(3), 542-65. http://search.proquest.com/docview/1305668504?fr__id=info\%3Axri\%2Fsid\%3Aprimo

Christine Oliver. (1997). The Influence of Institutional \& Task Environment Relationship on Organizational 
$\begin{array}{llll}\text { Performance. The Canadian } \quad \text { Construction } & \text { Industry, } & 34(1), & \text { 99-110. }\end{array}$ http://onlinelibrary.wiley.com/doi/10.1111/1467-6486.00044/full

Daft, R. L., Sormunen, J., \& Parks, D. (1988). Chief executive scanning, environmental characteristics, and company performance: An empirical study. Strategic Management Journal, 9, 123-139. https://doi.org/10.1002/smj.4250090204

El-Ansary, Adel I, \& Louis W. (1992). Stern. Marketing channels. Prentice-Hall,

Elsbach, Kimberly D. (1994). Managing Organizational Legitimacy in California Cattle Industry: The Construction and Effectiveness of Verbal Accounts. Administrative Science Quarterly, 39(3), 57-88. https://doi.org/10.2307/2393494

Farashahi M, Hafsi T, Molz R. (2005). Institutionalized norms of conducting research and social realities: a research synthesis of empirical works from 1983 to 2002. International Journal of Management Reviews, 7(1), 1-24. https://doi.org/10.1111/j.1468-2370.2005.00104.x

Frazier G L, Gill J D, Kale S H. (1980). Dealer dependence levels and reciprocal actions in a channel of distribution in a developing country. The Journal of Marketing, 1989, 50-69. http://www.jstor.org/stable/1251524?sid=primo\&origin=crossref

Frazier G L, Rody R C. (1991). The use of influence strategies in interfirm relationships in industrial product channels. The Journal of Marketing, 52-69. https://doi.org/10.2307/1252203

Ganesan S. (1994). Determinants of long-term orientation in buyer-seller relationships. The Journal of Marketing, 58(2), 1-19. https://doi.org/10.2307/1252265

Gaski. John. (1984). The Theory of Power and Conflict in Channels of Distribution. Journal of Marketing, 48(Summer), 9-29. http://search.proquest.com/docview/1296567877?rfr_id=info\%3Axri\%2Fsid\%3Aprimo

Geyskens I, Steenkamp J B E M, Kumar N. (1999). A meta-analysis of satisfaction in marketing channel relationships. Journal of marketing Research, 136(2), 223-238. https://doi.org/10.2307/3152095

Goll, I. \& Rasheed, A. (1997). Rational decision-making and firm performance: the moderating role of environment. Strategic Management Journal, $\quad$ 18(7), 583-591. https://doi.org/10.1002/(SICI)1097-0266(199708)18:7<583::AID-SMJ907>3.0.CO;2-Z

Granovetter, M.S. (1985). Economic action and social structure: the problem of embeddedness . American Journal of Sociology, 91, 481-510. https://doi.org/10.1086/228311

Hunt, S. and Nevin, J. (1974). Power in a channel of distribution: sources and consequences. Journal of Marketing Research, 11(5), 186-93. https://doi.org/10.2307/3150557

Joskow, Paul L. (1985). Vertical Integration and Long Term Con- tracts: The Case of Burning Electric Generating Plants. Journal of Law, Economics and Organization, 1(Spring), 33-80. http://web.a.ebscohost.com/ehost/detail/detail?sid=97bbef07-98c7-41fd-b3f1-fb06ea9aad06\%40sessionmgr400 9\&vid=0\&hid=4101\&bdata=Jmxhbmc9emgtY24mc210ZT1laG9zdC1saXZl\#AN=26371728\&db=buh

Kale, Sudhir. (1986). Dealer Perceptions of Manufacturer Power and Influence Strategies in a Developing Country. Joumal of Marketing Research, 23(11), 387-93. https://doi.org/10.2307/3151815

Kasulis, Jack \& Robert Spekman. (1980). A Framework for the Use of Power. European Journal of Marketing, 14(4), 18-27. https://doi.org/10.1108/EUM0000000004899

Kostova, Tatiana \& Srilata Zaheer. (1999). Organizational Legitimacy Under Conditions of Complexity: The Case of Multinational Enterprise. Academy of Management Review, 24(1), 64-81. http://www.jstor.org/stable/259037

Krapfel, Robert E. \& Robert Spekman. (1995). Channel Power Sources, Satisfaction and Performance: An Exploration. in AMA Winter Educators' Conference, Russell W. Belk and Gerald Zaltman, eds. Chicago: American Marketing Association, 30-34.

Kumar N, Scheer L K, Steenkamp J B E M. The effects of perceived interdependence on dealer attitudes. Journal of marketing research,

348-356. http://web.a.ebscohost.com/ehost/detail/detail?sid=f04dae8c-3a22-46d3-8789-ad24a50dfcd5\%40sessionmgr400 8\&vid=0\&hid=4101\&bdata=Jmxhbmc9emgtY24mc210ZT1laG9zdC1saXZl\#AN=9508240980\&db=bu

Meyer J W, Rowan B. (1977). Institutionalized organizations: Formal structure as myth and ceremony. American journal of sociology, 340-363. https://doi.org/10.1086/226550 
Mezias, Stephen J. (1990). An Institutional Model of Organizational Reporting Practices: Financial Reporting at Fortune 200. Administrative Science Quarterly, 35(9), 431-457. https://doi.org/10.2307/2393312

Nunnally, J. C., I. H. Bernstein. (1994). Psychometric Theory. 3rd ed. McGraw-Hill, New York.

Oliver, Christine. (1991). Strategic Responses to Institutional Processes. Academy of Management Review, 16(1), 145-179. https://doi.org/10.5465/AMR.1991.4279002

Pfeffer J, G R Salancik. (1977). The external control of organizations: A resource dependence perspective. New York: Harper and Rbulishers, 573-582.

Rasheed, A. \& Prescott, J. (1992). Towards an objective classification scheme for organizational task environments. British Journal of Management, 3(4), 197-206. https://doi.org/10.1111/j.1467-8551.1992.tb00045.x

Raven, Bertram \& Arie ICruglanski. (1970). Conflict and Power, in The Structure of Conflict. Paul Swingle, ed. New York: Academic Press, Inc., 69-109.

Scott W R. (1987). The adolescence of institutional theory. Administrative science quarterly, 32(4), 493-511. https://doi.org/10.2307/2392880

Steiger, J. H. (1990). Structural model evaluation and modification: An interval estimation approach. Multivariate Behavioral Research, 25, 173-180. https://doi.org/10.1207/s15327906mbr2502_4

Van de Ven A H, Delbecq A L, Koenig Jr R. (1976). Determinants of coordination modes within organizations. American sociological review, 27, 322-338. http://www.jstor.org/stable/2094477? sid=primo\&origin=crossref

Van de Ven A H, Delbecq A L. (1974). A task contingent model of work-unit structure. Administrative Science Quarterly, 43, 183-197. https://doi.org/10.2307/2393888

Williamson O E. (1991). Comparative economic organization: The analysis of discrete structural alternatives. Administrative science quarterly, 32, 269-296. https://doi.org/10.2307/2393356

Zucker, Lynne G. (1983). "Organizations as Institutions," in Research in the Sociology of Organizations, S.B. Bacharach, ed. Greenwich, CT: JAI Press.

Zucker, Lynne G. (1997).The Role of Institutionalization in Cultural Persistence. American Sociological Review, 42(10), 726-43. http://www.jstor.org/stable/2094862?sid=primo\&origin=crossref 